\title{
Inventory: The pesticides application and its risk assessment in the irrigated perimeter of Tadla-Morocco
}

\author{
Fatima Zahra Hafiane ${ }^{1, *}$, Hind El Bouzaidi ${ }^{1}$, Nordine Nouayti' ${ }^{2}$, Latifa Tahri' ${ }^{1}$, Mohamed El Jarmouni ${ }^{2}$, \\ Salahdine Didi ${ }^{3}$, Mohammed Fekhaoui' ${ }^{1}$
}

\begin{abstract}
${ }^{1}$ Geo-Biodiversity and Natural Patrimony Laboratory GEOPAC Research Center, Mohamed V University in Rabat, Scientific Institute, B.P. 1040, Rabat, Morocco; e-mail: : f.s.h.hafiane@gmail.com (F.Z.H., " corresponding author); hind.bouzaidi89@gmail.com (H.E.B.); lattahri@gmail.com (L.T.); uhe_isr@yahoo.com (M.F.)

${ }^{2}$ Laboratory of water and environmental engineering, Abdelmalek Essaadi University, National School of Applied Sciences, B.P03, Al-Hoceima, Morocco; e-mail: nordine.svt@gmail.com (N.N.); med.eljarmouni@gmail.com (M.E.J.)

${ }^{3}$ Department of Geology, Sultan Moulay Slimane University, Faculty of Science and Technology, B.P. 524, Beni-Mellal, Morocco; e-mail: salah2stu@gmail.com
\end{abstract}

\begin{abstract}
The industrialization of the agricultural sector increases the use of pesticides, which are composed of chemical substances, such as herbicides, fungicides, insecticides, acaricides, nematicides, and rodenticides, that are adapted to the control of undesirable plants and animals. All these phytosanitary products have varying degrees of toxicity, which risks human life. This study aimed to make an inventory of the pesticides used in the irrigated perimeter of Beni Moussa and Beni Aamir in the Beni Mellal-Khenifra region. The data collection through questionnaires took place between January and February 2016 and covered all the study areas. The questionnaires are focused on the mode of packaging management, sale and purchase of pesticides. The results demonstrated the existence of different pesticides and active substances used for crop protection in the region. Among 63 molecules, 14 active substances were detected, where the active substances are not approved by the world health organization, which considers it as carcinogenic substances. During phytosanitary treatments by farmers, these active substances come into direct contact with the soil, presenting a permanent risk to the environmental compartments, including groundwaters.
\end{abstract}

Key words: Inventory - pesticides; sanitary risk; Mio-plio-quaternary aquifer; Tadla Plain

\section{Introduction}

Since the mid-20th century, synthetic organic products have been developed and highlighted as a biocide. It started with the emergence of the first scientific studies on the use of chemicals for crop protection and the fight against pest and disease. Some products are extracted from plants for long time ago, as the antiparasitic, that was discovered in china almost 2000 years ago (Randhavane 2019); as well as the nicotine, which is used to control aphids since the beginning of the 19th century (Abdellaoui et al. 2018; Lee et al. 2019). Among the mineral products, the copper acetoarseniate (Paris green) is used against mosquito larvae since the beginning of the century. But the great technological revolution is the discovery of synthetic organochlo- rinated compounds: $\mathrm{HCH}$ (hexachlorocyclohexane) in 1937 and DDT in 1939, followed by the discovery of organophosphorus compounds and the parathion in 1944. The discovery of the insecticidal effect of DDT by Muller in Switzerland in 1939 has revolutionized the fight against the insecticide pests for crops and the fight against the major endemics diseases (Deadman 2017; Abdellaoui et al. 2018). The first organophosphorus compounds are developed in Germany for military purposes.

More than 300 products of this family are currently in the market, where the earliest products are highly toxic (parathion). At the same time, the recent products are less toxic and biodegradable (malathion). The carbamates appeared for the first time in 1955. Then they became well known domestic insecticides as propoxur (baygon) (Deadman 2017). 
Within the initial success of the pesticides, the development of agriculture and the desire to increase yields have led to increased pesticide deployment, which causes environmental contamination and a large number of aquifers pollution (Jouzel and Prete 2014). The pesticides and toxic molecules are designed to eliminate all harmful organisms for crops and they are characterized according to their roles (Rastija et al. 2017). There are three main groups: insecticides, herbicides, fungicides, and more than 7,000 commercial formulations are known (Marutescu and Chifiriuc 2017). These molecules are very diverse in their chemical behavior. Thus, each substance has its characteristics, which make it more or less persistent in our environment. The use of these substances in agriculture with different methods plus the effective disposal technique for pesticide application can provide an integrated approach to weed, pest and disease control (Samadi-Maybodi and Rahmati 2019).

In Morocco, the population growth and the desire to improve the life level in rural areas require an increase in agriculture productivity, which can be achieved by improving crop management through the adoption of efficient cultivation techniques (Choi et al. 2016; Maftouh et al. 2017). The synthetic phytosanitary products are very useful and reliable in a significant number of cases and over large areas. Moroccan agriculture has developed production systems based on these products, which makes agriculture depend on the pesticides used (Agnaou et al. 2017). The pesticides are often used at a high rate and are misapplied, leading to groundwater and surface water pollution (Reiler et al. 2015).

Apart from the regulatory aspect, the pesticides sector in Morocco remains under a low control in terms of statistics and information. The implementing texts regulating pesticides are provided by several decrees and orders, including Law No. 42-95, Law No. 32-00, Decree No. 2-99-105, Decree No. 2-99-106, Decree No. 2-01-1343, Order No. 3164-12 (AMPP 2020). This situation is mainly due to the lack of inter-professional coordination of companies operating in the import, formulation and distribution of phytosanitary products, and aggravated by the illegal infiltration of these products from neighboring countries (Srad'ri 2017). The absence of phytosanitary product manufacturing units makes Morocco import 95\% of products (an aver- age of 1,425 tons per year). At the same time, the rest is formulated based on premixes or concentrates (El Houssain et al. 2019). These phytosanitary products' complexity and diversity require regular monitoring and control of water intended for recharge, especially in rural areas, where people drink wells water (Maatala et al. 2019). Indeed, from all intoxication cases in Morocco in recent years, pesticides are incriminated in 5\% of cases (Boukatta et al. 2014).

The irrigated perimeter of Tadla knows a high agricultural activity. The phytosanitary products contribute, making this region one of the most significant agricultural zones in Morocco with good quality and a large quantity of its crops. The deterioration of the groundwater quality is one of the major environmental outcomes of the modernization of cultivation in this perimeter (Oumenskou et al. 2018; Hafiane et al. 2020). In response to this situation, several scientific investigations have been carried out on water contamination. On the other hand, scientific research on pesticides is very limited or rather non-existent in some areas, which has prompted us to develop this line of research. This study seeks to elucidate the reasons that must be taken as a basis for identifying the various toxic chemical molecules that could spread out and contaminate the quality of groundwater according to the following objectives: (i) analyze the agricultural knowledge, attitudes and practices, (ii) identify the various uses of phytosanitary products, and (iii) diagnose the potential for groundwater contamination.

\section{Materials and Methods}

\section{Study area}

The plain of Tadla (Fig. 1) is located in the province of Beni-Mellal. It is crossed from East to West by the Oum-er-Rbia River with $160 \mathrm{~km}$ of length, which divides it into two large hydraulically independent irrigated perimeters: the perimeter of Beni-Amir and the perimeter of Beni-Moussa, respectively, on the right bank and left of the Oum-erRbia (Didi et al. 2019; El Mouatassime et al. 2019).

\section{Preparation of the questionnaires}

The survey involved preparing two questionnaires: an individual questionnaire that concerns 


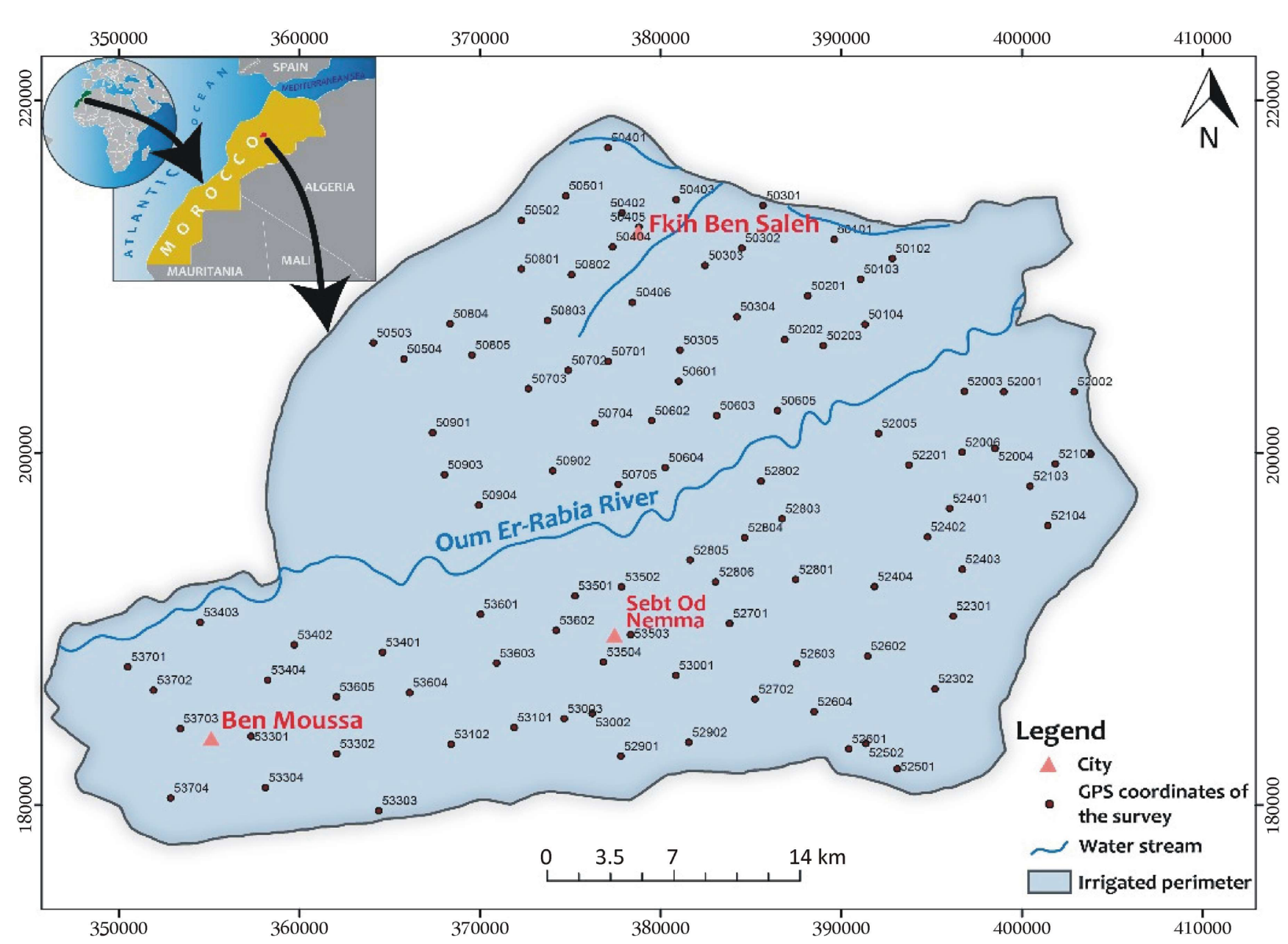

Fig. 1. Geographical location of the study area in central Morocco and distribution of farmers surveyed

farmers and concerns the vendors of phytosanitary products and technicians of the Agricultural Development Centre (ADC). These questionnaires were carried out on the basis of the stakes of our study in close collaboration with the conditions of our study field.

Thus, the different specific or common indicators to the various disciplines were identified, and the associated data. A consultation framework was set up in order to assess the exhaustiveness and clarity of the questions, the respondents' ability to answer them, the feasibility, the sensitivity of certain queries or consultation, and the general aspects related to the implementation of the survey (length of the questionnaire, age, processing period, etc.).

\section{Data collection and entry process}

The collection process lasted two months, from January to February (2016), with a frequency of 4 days per week. It was carried out by a team of four people with one interviewer throughout the study area. The farmers were selected at random in the localities. Survey supervision is ensured on half of the field by ORMVAT (Tadla Regional Agricultural Development Office) technicians. The survey forms analysis was carried out after coding the forms, where the input masks for the questionnaires are developed with Epi Info Version 3.5. Data entry for the 200 questionnaires was carried out over 4 weeks. The data files obtained were compatible with Microsoft Access and allowed the user who does not have Epi Info software to consult the data through an Access interface. The pesticides' active ingredients were determined using the list of phytosanitary products registered in Morocco. The data was exported to SPSS Statistics version 21.0 for data processing. Weightings, calculations, flat sorting, cross sorting, tabulations, and statistical tests were performed using this software. 


\section{Results and Discussion}

\section{Supply of agricultural inputs}

\section{Distribution, sales and purchases}

In Morocco, to carry out this activity, including the import, manufacturing, and distribution of pesticide products, companies need an approval certification and authorization for sale, issued by the Ministry of Agriculture and Fisheries under the conditions stipulated by the Law 42-95 and its implementing texts (Law 42-95).

According to the latest statistics, 61 phytosanitary companies are approved to exercise this activity. The number is expected to increase and reach 70 companies view several requests for approvals that have been revised according to ONSA (National Office for Sanitary Safety of Food Products) and supported by other authors (Rhalem et al. 2009; Barakat et al. 2016; Maatala et al. 2019; El Bouzaidi et al. 2020). The phytosanitary market in Morocco is diversified and attractive, where many companies are in legal competition (Fig. 2).

According to the survey results, $81.6 \%$ of farmers obtain their pesticides from the souk (local market), giving that illegal trafficking is flourishing, while $18.4 \%$ buy their products from specialized dealers. The survey also showed that $92 \%$ of farmers chose phytosanitary products based on technicians' recommendations, while $8 \%$ make choices based on their experience (Fig. 3).

\section{Acute pesticide poisoning}

There is interest in acute pesticide poisoning, which has a direct relationship between exposure and the appearance of symptoms, as reported by Rahhal et al. 2017, Hassoun et al. 2017, Iken et al. 2018, Krakowiak et al. 2019 and Kim 2020. Data on the nature of the following pesticide poisonings were obtained during the survey of 3 provinces, 17 rural communes and 27 douars (temporary Arab settlements). Despite repeated requests, no data could be obtained from the authorities responsible for poisoning information (Fig. 4).

\section{Classification of pesticides used and active ingre- dients identified}

The used pesticides in Morocco are not locally produced. They are imported from abroad. Approx. 300-350 active ingredients are authorized and used in the composition of nearly 1,000 com-

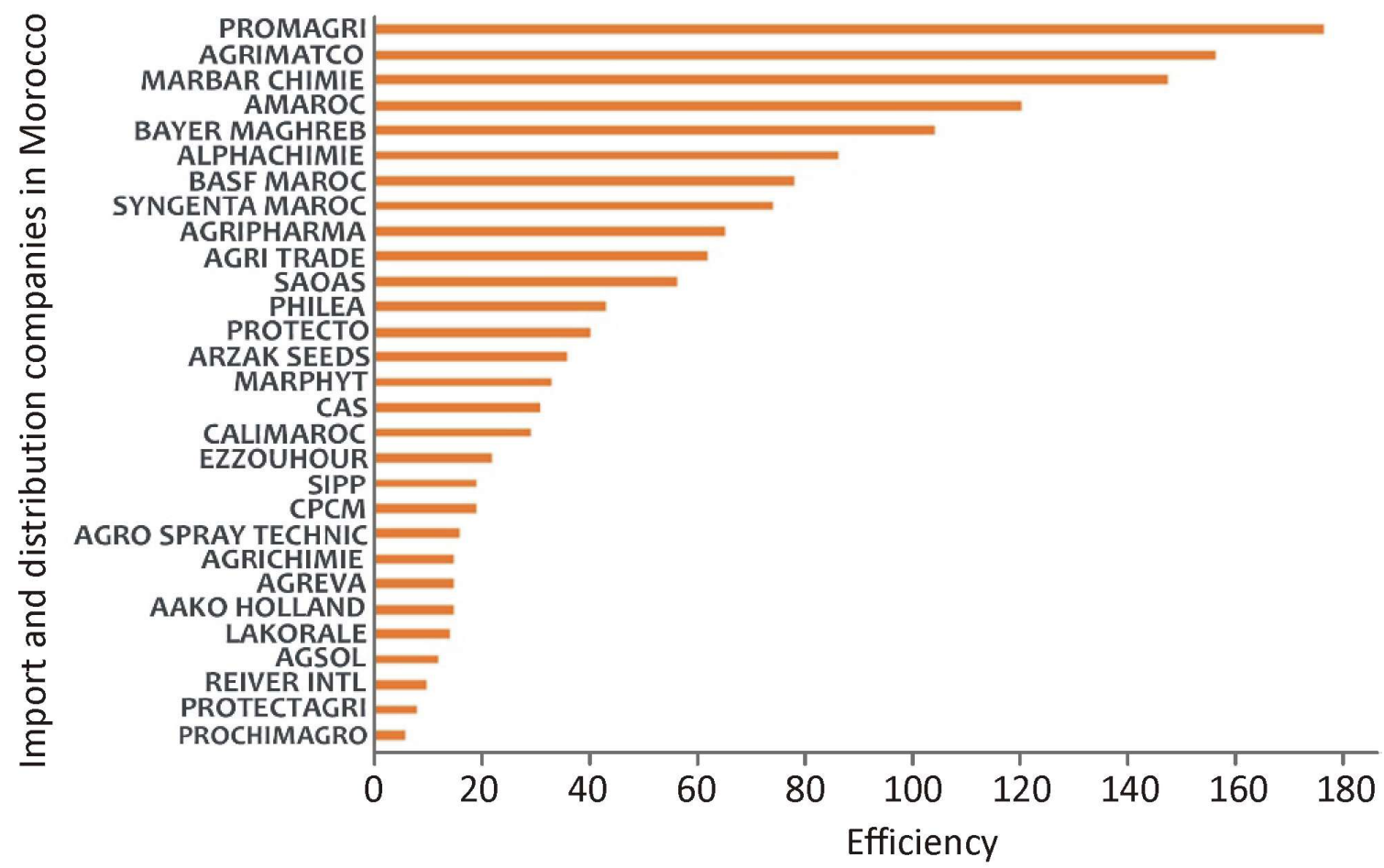

Fig. 2. Companies importing and distributing phytosanitary products and fertilizers 


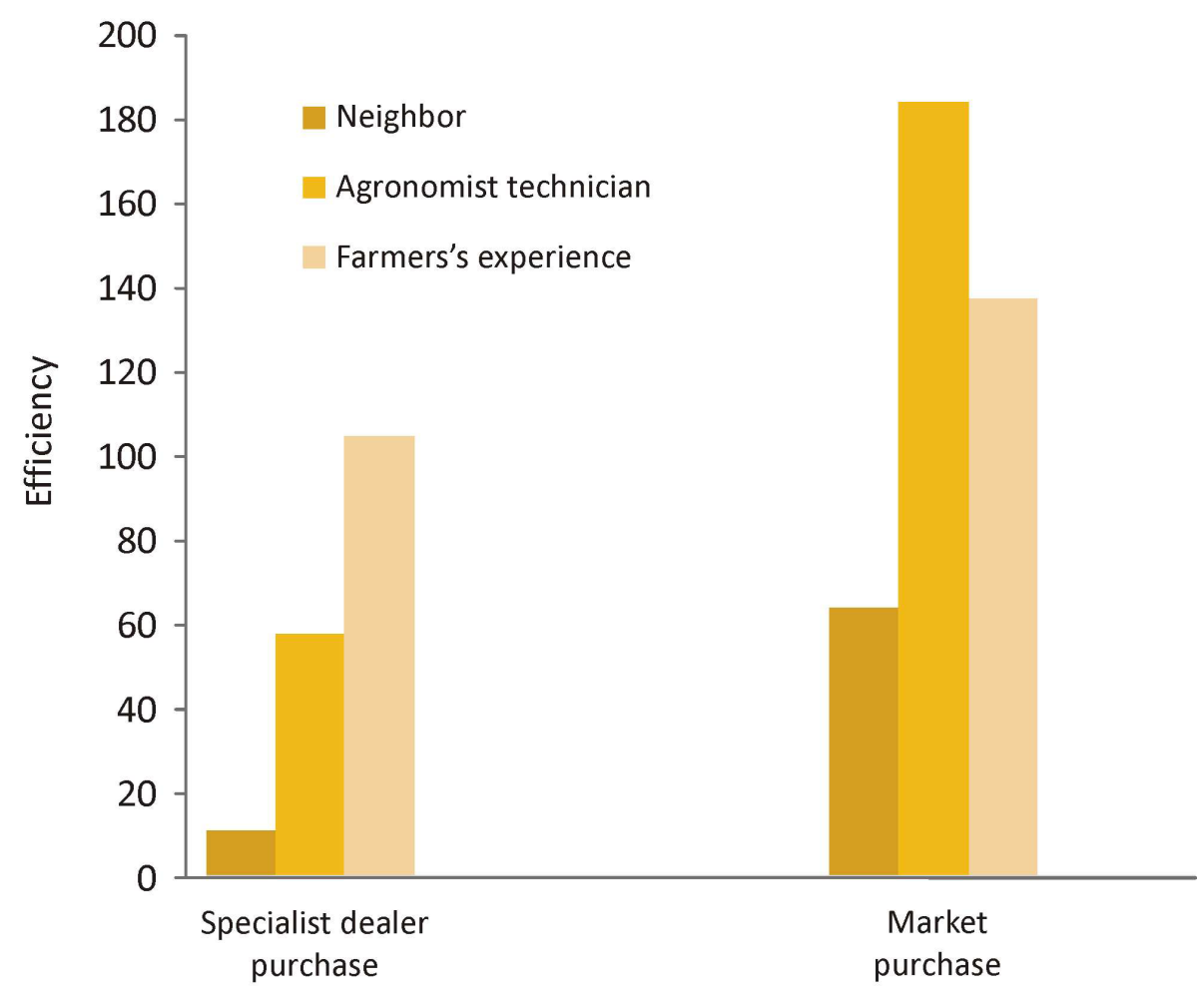

Supply of plant protection products

Fig. 3. Mode of supply of phytosanitary products among respondents

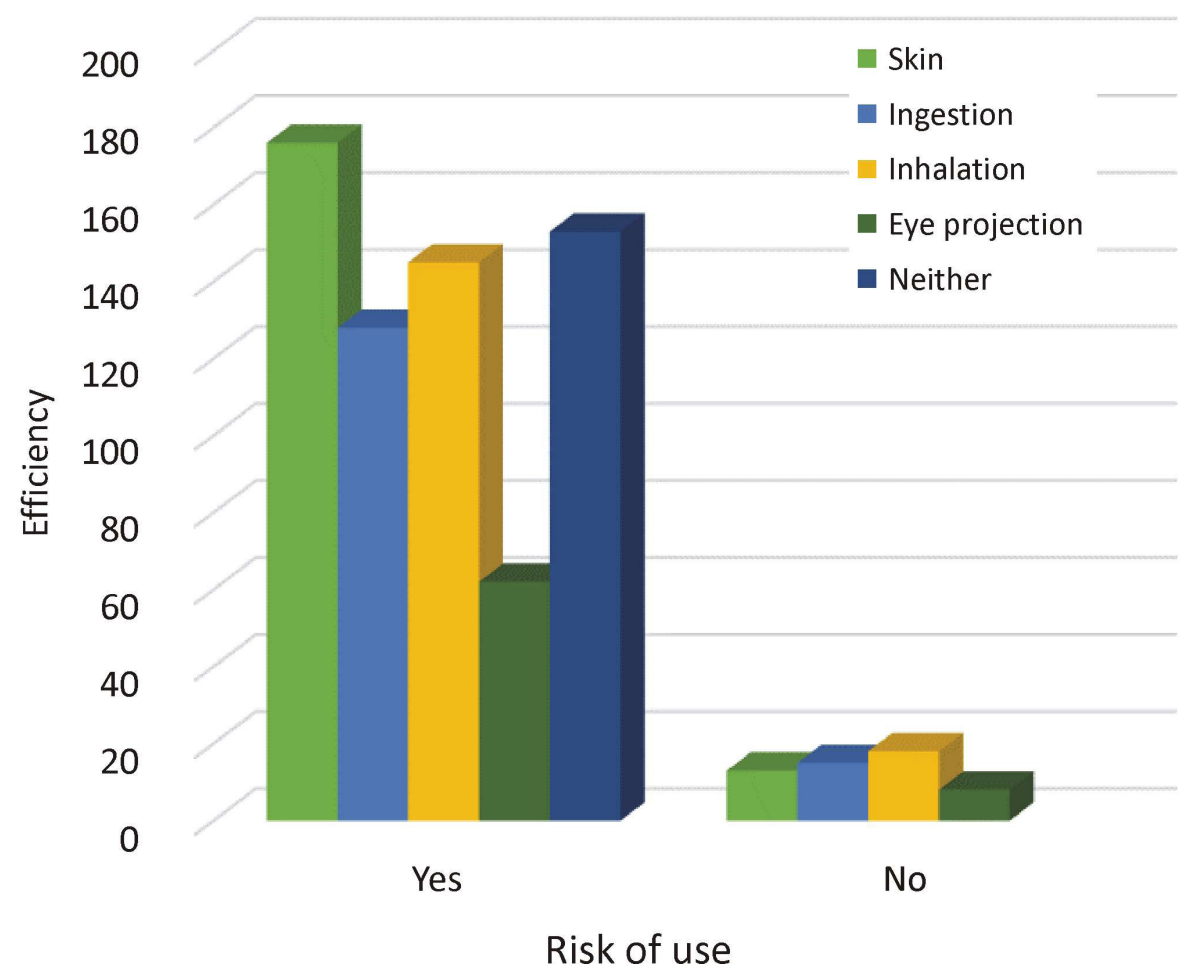

Fig. 4. Nature of pesticide poisoning among farmers 
mercial products, of which more than $80 \%$ are registered for agricultural uses (Detsouli et al. 2017; El Houssain et al. 2019; Velkoska-Markovska et al. 2019).

According to the survey, three main categories of products were distinguished (Fig. 5). The first category is constituted of herbicides (33\%) considered as the most consumed products in the zone, whose role is destroying invasive plants (weeds). The most often used families include triazines, atrazine, simazine, cyromazine, terbumeton, uracils and substituted ureas (linuron, isoproturon, Granstar, Mustang, diuron). These results are similar to studies showed by Mehmeti et al. 2016 and WHO 2020. The second one includes insecticides (29\%), whose role is to eliminate insects. The most important chemical families are carbamates (carbosulfan), organophosphates (dichlorvos, malathion), pyrethrum derivatives in the form of synthetic products (bifentrin, cypermethrin), and organophosphates (bromophos). These results are compatible to those from other studies (Agnaou et al. 2018; El Yousfi et al. 2020). The last category includes fungicides $(28.32 \%)$, whose role is fighting against fungi. The most commonly used products are synthetic organics, where many groups could be distinguished, including carbamates (benomyl, carbendazim), derivatives of benzene and phenol, triazoles (flusilazole, tebuconazole, difenoconazole) and amides (carboxin), These results support the view presented by Mehmeti et al. 2016 and Ngakiama et al. 2019.

\section{Inventory of pesticides marketed in the study zone}

A variety of common pesticides and active ingredients are marketed for crop protection in the study area. These data are presented as supplementary material (Table 1 ). The pesticide's trade name does not depend on the active ingredient it contains, but it highly depends on the manufacturer. For example, several pesticides sold under different trade names contain the same active ingredient. For example, nine herbicides are marketed under various names to control grassy fields with the same active ingredient glyphosate, where the concentration varies from one product to another. Glyphosate belongs to class III of toxicity, with a relatively low risk for human life and for the environment. Other selective herbicides with the same active ingredient of petroleum oil are marketed in the study area with a very high frequency under the name of SEPPIC 11E.

Concerning the insecticides, seven products are marketed under various names with the same active ingredient of malathion. Where a product that is high commercialized with the same active compound of cypermethrin belongs to class II of toxicity, with a quite dangerous effect on humans and on the environment, these results are in accordance with other studies (El Azzouzi et al. 2014; Iken et al. 2018; Kpan Kpan et al. 2019; El Bouzaidi et al. 2020).

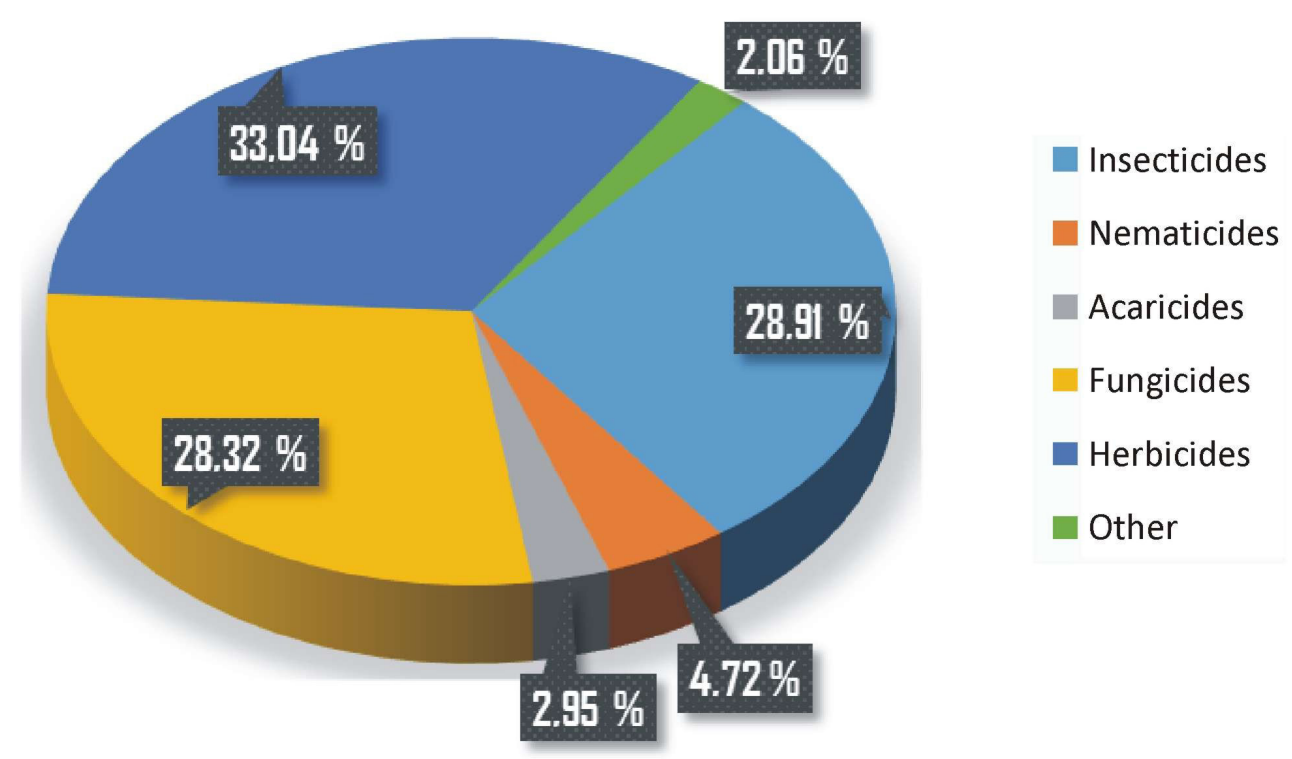

Fig. 5. Categories of pesticide products used in the survey area 
Table 1 . Inventory of the most commercially marketed pesticides in the study area

\begin{tabular}{|c|c|c|c|}
\hline Trade name & Active substance & Type & Company \\
\hline CYPAGRI & Cypermethrin & Insecticide & AGRIMATCO \\
\hline $\begin{array}{l}\text { SEPPIC } 11 \mathrm{E} \\
\text { SAF-T-SIPE }\end{array}$ & Petroleum oil & $\begin{array}{l}\text { Herbicide } \\
\text { Insecticide }\end{array}$ & $\begin{array}{l}\text { MARBAR CHIMIE } \\
\text { AGRPHARMA }\end{array}$ \\
\hline DORMAK 40 & Tetraconazole & Fungicide & REIVER INT’L \\
\hline $\begin{array}{l}\text { ACTELLIC 50EC } \\
\text { RELDAN } 40\end{array}$ & Chlorpyriphos-methyl & Insecticide & $\begin{array}{l}\text { MARBAR CHIMIE } \\
\text { PROGMAGRI }\end{array}$ \\
\hline $\begin{array}{l}\text { CALLIMAL } 50 \\
\text { MALAPROM } \\
\text { KEYTHION }\end{array}$ & & & $\begin{array}{c}\text { CALIMAR } \\
\text { AGRO SPARAY TECHNIC } \\
\text { AGREVA }\end{array}$ \\
\hline $\begin{array}{l}\text { MALYPHOS } 50 \\
\text { PROSTORE } 420 E C\end{array}$ & Malathion & Insecticide & $\begin{array}{l}\text { AGRI-CHIMIE } \\
\text { BASF MAROC }\end{array}$ \\
\hline SIF MALATHION 50 & & & AMAROC \\
\hline SUPERATHION 5OEC & & & EZZOUHOUR \\
\hline CONDOR F & & & PROMAGRI \\
\hline $\begin{array}{l}\text { DD-90 } \\
\text { DORLONE EC } \\
\text { DD92 }\end{array}$ & 1,3-Dichloropropene & Nematicide & $\begin{array}{c}\text { SIPP } \\
\text { CAS } \\
\text { AMAROC }\end{array}$ \\
\hline TRACER 480SC & Spinosade & Insecticide & PROMAGRI \\
\hline $\begin{array}{l}\text { CENTAURE } \\
\text { CLINIC }\end{array}$ & & & $\begin{array}{c}\text { CPCM } \\
\text { AMAROC }\end{array}$ \\
\hline $\mathrm{KALACH}$ & & & CALIMAROC \\
\hline MAMBA & & & PROMAGRI \\
\hline RONDO & Glyphosate & Herbicide & LAKORALE \\
\hline OVNI XL & & & SAOAS \\
\hline ROUND'UP ENERGY & & & AGRIMATCO \\
\hline OURAGAN 4 & & & SYNGENTA MAROC \\
\hline ROUND’UP & & & ALFACHIMIE \\
\hline KARATE 2ULV & Lambda-cyhalothrine & Insecticide & SYNGENTA MAROC \\
\hline ALFAHD MIX & 2,4-D(acid salts aluminum) $+\mathrm{MCPA}$ & Herbicide & СРCM \\
\hline $\begin{array}{l}\text { CYREN 480EC } \\
\text { DURSBAN } 75 \\
\text { LORSBAN 5G }\end{array}$ & & & $\begin{array}{c}\text { AGRO SPARAY TECHNIC } \\
\text { PROMAGRI } \\
\text { PROMAGRI }\end{array}$ \\
\hline $\begin{array}{l}\text { KEMABAN 10G } \\
\text { DURSBAN } 4 \\
\text { PYRICAL } 480 \\
\text { ULTRAPHOS }\end{array}$ & Chlorpyriphos-ethyl & Insecticide & $\begin{array}{l}\text { ARZAK SEEDS } \\
\text { PROMAGRI } \\
\text { CALIMAROC } \\
\text { AGSOL }\end{array}$ \\
\hline GRANSTAR & Tribenuron-methyl & Herbicide & AGRIMATCO \\
\hline TOPIK O8OEC & Clodinafop propagyl + Cloquintocet mexyl & Fungicide & AMAROC \\
\hline SELECT & Clethodim & Herbicide & MARBAR CHIMIE \\
\hline ERBUS 350LS & Acetate de Guazatine & Fungicide & ALPHACHIMIE \\
\hline $\begin{array}{l}\text { EL AFRIT } 200 \\
\text { EL GHOUL } \\
\text { EL AFRIT } 480\end{array}$ & 2,4-D(ester butylglycol) & Herbicide & $\begin{array}{l}\text { AMAROC } \\
\text { SIPP } \\
\text { AMAROC }\end{array}$ \\
\hline $\begin{array}{l}\text { TRACTOR 10EC } \\
\text { CONCORD 100EC }\end{array}$ & Alphacypermethrin & Insecticide & $\begin{array}{l}\text { PROTECTO } \\
\text { PROGMAGRI }\end{array}$ \\
\hline PROZARO 250EC & Prothioconasol + Tebuconasol & Fungicide & BAYER MAGHREB \\
\hline PEROCLAIM & Enamectin benzoate & Insecticide & SYNGENTA MAROC \\
\hline JADARME 25WP & Methomyl & Insecticide & SAOAS \\
\hline $\begin{array}{l}\text { ENDOSULFAN } 35 \\
\text { SPENDOS EC } 35\end{array}$ & Endosulfan & Insecticide & $\begin{array}{l}\text { CALIMAROC } \\
\text { PHILEA }\end{array}$ \\
\hline
\end{tabular}


Table 1. Continuation

\begin{tabular}{|c|c|c|c|}
\hline AKODIM & Clethodim & Herbicide & AAKO HOLLAND \\
\hline DIVANE 50EC & Dichlorvos & Insecticide & EZZOUHOUR \\
\hline FURY 100EW & Zeta-cypermetrine & Insecticide & BASF MAROC \\
\hline GOLDAZIM 500EC & Carbendazim & Fungicide & PHILEA \\
\hline CUPRA 50 & Copper oxide & Fungicide & PROCHIMAGRO \\
\hline $\begin{array}{l}\text { CUBROX } \\
\text { COPAS }\end{array}$ & Copper + sulphate $(\mathrm{BB})$ & Fungicide & $\begin{array}{c}\text { AGRICHIMIE } \\
\text { AGREVA }\end{array}$ \\
\hline $\begin{array}{l}\text { FURADAN } 5 G \\
\text { AXLERA 5G }\end{array}$ & Carbofuran & $\begin{array}{l}\text { Insecticide/Nemati- } \\
\text { cide }\end{array}$ & $\begin{array}{c}\text { BASF MAROC } \\
\text { MARBAR CHIMIE }\end{array}$ \\
\hline $\begin{array}{c}\text { COSAVET DF } \\
\text { MICROTHIOL SPECIAL }\end{array}$ & Micronized sulphur & Fungicide & $\begin{array}{c}\text { CAS } \\
\text { PROGMAGRI }\end{array}$ \\
\hline GARDNER & Difenoconazole & Fungicide & ARZAK SEEDS \\
\hline TEBUZOL & Tebuconazole & Fungicide & AGRI TRADE \\
\hline IMPACT RM & Flutriafol + Carbendazim & Fungicide & MARBAR CHIMIE \\
\hline PEROCLAIM & Enamectin benzoate & Insecticide & SYNGENTA MAROC \\
\hline COMODOR & Cyproconazol + Azoxytrobin & Fungicide & SYNGENTA MAROC \\
\hline PALLAS 45OD & Pyroxsulam + Cloquintocet-methyl & Herbicide & PROGMAGRI \\
\hline EMINENT STAR & Chlorothalonil + Tetraconazol & Fungicide & MARBAR CHIMIE \\
\hline MUSTANG 306 & 2,4-D + Florasulam & Herbicide & PROGMAGRI \\
\hline KENOPEL & Guazatine & Fungicide & AGRIPHARMA \\
\hline INDAR 5 EC & Fenbuconazol & Fungicide & AGRIMATCO \\
\hline TRIGARD 100SL & Cyromazin & Insecticide & SYNGENTA MAROC \\
\hline МАTCH 050EC & Lufenuron & Insecticide & SYNGENTA MAROC \\
\hline MERJAN & Captan & Fungicide & SAOAS \\
\hline PROLINURON & Linuron & Herbicide & PROGMAGRI \\
\hline SHARDABAN & Chlorpyriphos & Insecticide & PROTECTAGRI \\
\hline OLYMP 10EW & Flusilazol & Fungicide & AGRIMATCO \\
\hline TREFLAN & Trifluralin & Herbicide & BAYER MAGHREB \\
\hline
\end{tabular}

\section{Chemical molecules of pesticides marketed in the study zone}

In this study, 63 substances are identified through the trade names of pesticides. Abbreviation/common names for substances classes used as anthropogenic markers and their physicochemical properties are presented in the supplementary material (Table 1), which are considered dangerous or potentially dangerous by American (Environmental Protection Agency), European (database managed by the European Commission), and by the International (Agency for Research on Cancer) organizations. The same results are reported in previous studies (Rhalem et al. 2009; Iken et al. 2018; Krakowiak et al. 2019; Kim 2020) (Fig. 6). Carbofuran, petroleum oil, trifluralin, glyphosate are at the top of our ranking with big quantities.

It is well-known that exposure to pesticides is dangerous to humans. Several pesticides are now banned from use due to their toxicity. However, they still persist in soil and water because of their long lifespan, especially since some farmers still use them illegally. These results are in agreement with other studies (Agnaou et al. 2017, 2018; Iken et al. 2018). Among 63 molecules, 14 active substances are prohibited and considered probably carcinogenic (Fig. 7). Walton (2016) stated that the carbofuran was already banned in 1993 (FURADAN 5G), new bans in 1998, and then in 2004, 2008. In addition, Tadeo et al. (2008) reported that the use of the malathion, which is banned in Europe since 2007. Also, the 1,3-dichloropropene is banned since 2009, because it is highly toxic and probably carcinogenic, mutagenic and neurotoxic (Tadeo et al. 2008; Eddaya et al. 2015). Petroleum oil, a product that is used with other substances, is also banned but allowed in certain uses as an adjuvant for herbicides and insecticides. It is a new fashionable example of 


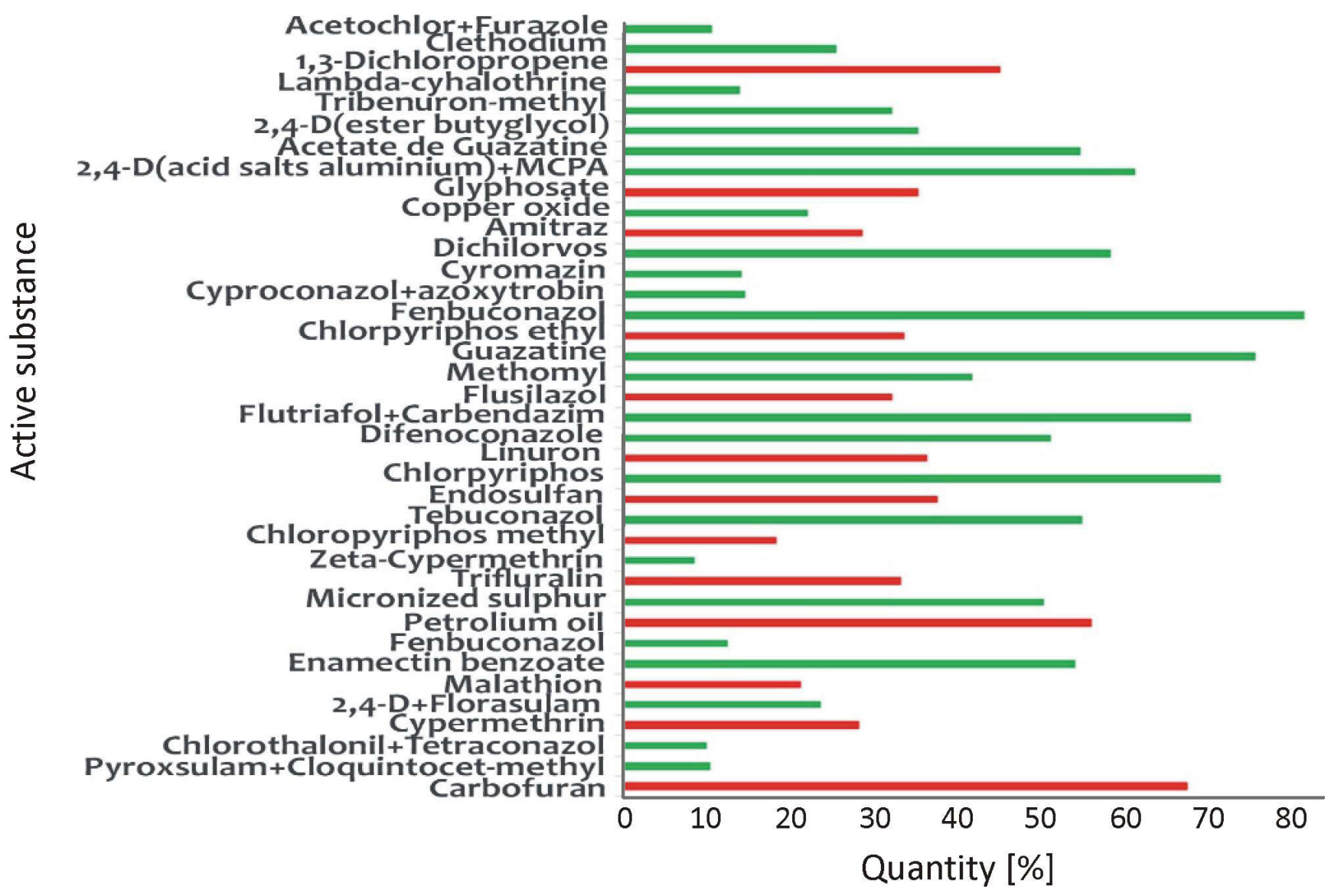

Fig. 6. Active substances identified in the phytosanitary products used by the farmers surveyed

the derogations trick, which looks like a deflection of the legislation, as reported in other studies (Tadeo et al. 2008; Cruzeiro et al. 2016; Liu et al. 2020) and concern is increasing about the potential harm to farmland soil. Four treatments (ATO, AT6, AT10, AT16. Of which, glyphosate, the most widely used herbicide globally and most often found in the environment, is banned by France since January 2016 ( Rojano-Delgado et al. 2012; Bouterfas et al. 2020) it is not without consequences for the environment and human health. In this context, we conducted a survey among 67 farmers in the Plain of Triffa of the Berkane region to analyze their phytosanitary practices and assess the risks to the environment and human health. $98 \%$ of the farmers have never received training on the use of pesticides. 181 different commercial specialty chemicals were inventoried. Insecticides (50\%. The acetochlor is banned by the European Union (EU) since December 2011, with a deadline for ending its uses until 2013 (Wal- ton 2016). Concerning the trifluralin, all products which contain the trifluralin are withdrawn from the market since 1991 (Canteiro et al. 2019). Also, the flusilazole is banned from the mid-2000s till 2014 (Koroša et al. 2016; Maftouh et al. 2017)their presence in groundwater is the result of current anthropogenic activity and pollution loads from the past. A study on the occurrence and concentrations levels of selected contaminants in water was performed in the city of Maribor, Slovenia. A total of 56 groundwater and 4 surface water samples were collected in together four rounds in different hydrogeological periods (dry and wet seasons. Finally, the chlorpyrifos-ethyl is banned in France since 1995 ( Singare 2016; Bouterfas et al. 2020).

\section{The methods of managing the packaging of the products used}

Four methods of packaging management are observed among producers in the irrigated area. Discarding, incineration, reuse and landfilling are 


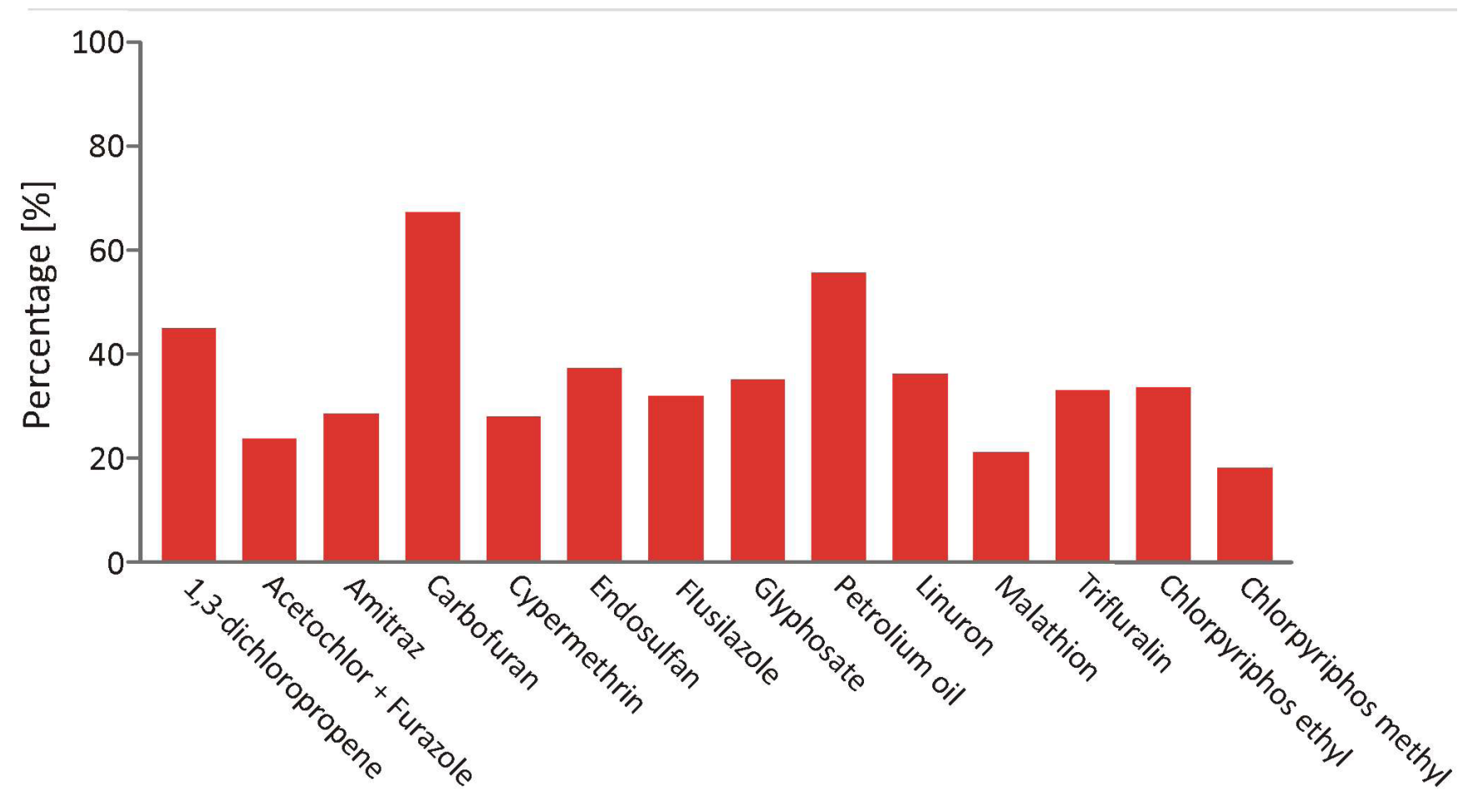

\section{Active substance}

Fig. 7. The world's best-selling banned active substances used

the four ways of managing the packaging of agricultural inputs (fertilizers and pesticides) (Fig. 8). The most common release mode is pesticide packaging to the environment, which presents $53.58 \%$, while some other producers practice burial (27.43\%), where incinerate and reuse present respectively
E्E Incineration
Landfill
Re-use
Discharge

$10.34 \%$ and $8.65 \%$. The main methods of waste disposal and burial could contribute to a decline in soil fertility after accumulation and the reuse could lead to a risk of poisoning. These results are in agreement with other studies reported by (Walton 2016; Rahhal et al. 2017; Krakowiak et al. 2019).
27.52

10.06

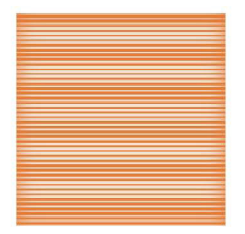

9.01

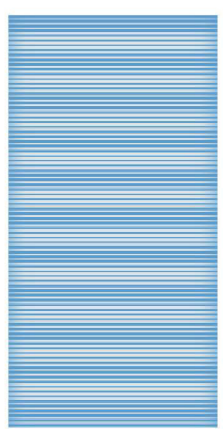

Fig. 8. Management modes for packaging of agricultural inputs used 


\section{Conclusion}

The use of pesticides presents a risk to the environment and human life. Then, in order to get an overview of the contamination of groundwater by pesticides, this preliminary study was carried out in the irrigated perimeter of Beni Amir and Beni Moussa. The results show a range of active substances, which are not approved worldwide. A combination of factors, such as the number of pesticides, pesticide transport mechanisms and the type of crop, may explain the presence of pesticide molecules in the groundwater. These substances are obviously undesirable in the groundwater because of the risk it presents to human life. For these reasons, several measures and criteria are studied through the survey to give a global vision to the managers and decision-makers to better manage pesticides in agriculture to protect and preserve the region's groundwater resources.

\section{Acknowledgments}

The authors are especially grateful to acknowledge the Department of agricultural development (DDA) of Tadla and the Department of irrigation and drainage network management (DGRID) of Tadla for their assistance in this study. The authors also would like to acknowledge the staff for their kind help in sampling collection.

\section{Conflict of interests}

The authors declare that there is no conflict of interests regarding the publication of this paper.

\section{References}

Abdellaoui K., Acheuk F., Miladi M., Boughattas I., Omri G., 2018, Phytochemistry, biochemical and insecticidal activities of Ruta Chalepensis essential oils on Tribolium Confusum, Agric. For. (Podgorica) 64(3): 31-45.

Agnaou M, Nadir M., Ait Alla A., Bazzi Lh., El Alami Z., Moukrim A., 2017, Organochlorine pesticides level evaluation in a Morocco Southern wetland: Massa Estuary, J. Mater. Environ. Sci. (JMES) 5(2): 581-586.

Agnaou M, Nadir M., Ait Alla A., Bazzi Lh., El Alami Z., Moukrim A., 2018, The occurrence and spatial distribution of pesticides in sea water of the Agadir Bay (South of Morocco), J. Mater. Environ. Sci. (JMES) 9(10): 3001-3008.
[AMPP] Association Marocaine de Protection des Plantes (Moroccan Association for the Protection of Plants), 2020, Index Phytosanitaire Maroc (Morocco Plant Health Index) (Accessed 16 February 2020). Retrieved from https://www.agrimaroc.ma/index-phytosanitaire-maroc/

Barakat A., El Baghdadi M., Rais J., Aghezzaf B., Slassi M., 2016, Assessment of spatial and seasonal water quality variation of Oum Er Rbia River (Morocco) using multivariate statistical techniques, Int. Soil Water Conserv. Res. 4(4): 284-292.

Boukatta B., El Bouazzaoui A., Guemoune R., Houari N., Achour S., Sbai H., 2014, An epidemiological study of adult acute poisoning in Fez: Morocco, J. Clin. Toxicol. 4(6): \#219.

Bouterfas M., Fadlaoui S., Chafik Z., El Halouani H, Melhaoui M., Chafi A., 2020, Evaluation of farmers' phytosanitary practices in the Plain of Triffa (Eastern Morocco), identification and evaluation of sanitary and environmental risks, Mor. J. Chem. 8(2): 345-358.

Canteiro M., Olea S., Escolero O., Zambrano L., 2019, Relationships between urban aquifers and preserved areas south of Mexico City, Groundw. Sustain. Dev. 8: 373-380.

Choi J.Y., Yang D.B., Hong G.H., Kim K., Shin K.-H., 2016, Ecological and human health risk from polychlorinated biphenyls and organochlorine pesticides in Bivalves of Cheonsu Bay, Korea, Environ. Eng. Res. 21(4): 373-383.

Cruzeiro C., Rocha E., Pardal M.A., Rocha M.J., 2016, Seasonal-spatial survey of pesticides in the most significant estuary of the Iberian Peninsula - the Tagus River estuary, J. Clean. Prod. 126: 419-427.

Deadman M.L, 2017, Sources of pesticide residues in food: Toxicity, exposure, and risk associated with use at the farm level, [in:] Khan M.S., Rahman M.S. (eds), Pesticide residue in foods: Sources, management, and control, Springer, Cham: 7-35.

Detsouli A, Amiar L., Nabih Z., Kharbouch D., Windy M., Rhalem N., Soulaymani A., Mokhtari A., SoulaymaniBencheikh R., 2017, Epidemiology of acute pesticide poisoning in Morocco: a 7-year retrospective study (2008-2014), J. Mater. Environ. Sci. (JMES) 8(12): 4234-4239.

Didi S., Housni F.E., del Toro H.B., Najine A., 2019, Mapping of soil salinity using the Landsat 8 image and direct field measurements: A case study of the Tadla Plain, Morocco, J. Indian Soc. Remote Sens. 47(7): 1235-1243.

Eddaya T., Boughdad A., Becker L., Chaimbault P., Zad'd A., 2015, Utilisation et risques des pesticides en protection sanitaire de la mentheverte dans le CentreSuddu Maroc (Use and risks of pesticides in sanitary protection of spearmint in south-central Morocco), J. Mater. Environ. Sci. (JMES) 6(3): 656-665 (in French). El Azzouzi E.H., El Bouzaidi H., Nouri K., El Azzouzi M., Fekhaoui M., 2014, study the impact of pesticides us- 
ing pressure indicator and toxicity watershed Merja Zerga (Morocco), Adv. Environ. Biol. 8(17): 31-35.

El Bouzaidi H., Hafiane F.Z., Fekhaoui M., 2020, Inventory of pesticides and their impact on the environment by calculating the frequency of treatment indicator in the Gharb plain (Morocco), Mediterr. J. Chem. (MJC) 10(4): 406-417.

El Houssain B., Fadlaoui A., Allali K., Arrach R., 2019, Contract farming in the Morocco Cereal Sector: Contract clauses, ambiguity, and opportunism, Int. J. Agric. Econ. 4(5): 245-253.

El Mouatassime S., Boukdir A., Karaoui I., Skataric G., Nacka M., Khaledi Darvishan A., Sestras P., Spalevic V., 2019, Modelling of soil erosion processes and runoff for sustainable watershed management: Case study Oued El Abid watershed, Morocco, Agric. For. (Podgorica) 65(4): 241-250.

El Yousfi K., Greche H., Misbahi H., Cheikh R.B, 2020, Phytochemical evaluation and vasodilatory activity of O. Elongatum, C. Salviifolius and C. Laurifolius, Mor. J. Chem. 8(1): 226-234.

Hafiane F.Z., Tahri L., Nouayti N., El Jarmouni M., Arifi K., El Amrani Idrissi A., Fekhaoui M., 2020, Assessment of spatial and seasonal nitrate variation of groundwater in the irrigated perimeter (Tadla Plain-Morocco), Agric. For. (Podgorica) 66(1): 203-314.

Hassoun H., Lamhasni T., Foudeil S., Lyazidi S.A., Haddad M., Choukrad M., Patrolecco L., Polesello S., Valsecchi S.M, 2017, implementation of total fluorescence fingerprinting as a rapid and low cost approach for monitoring pesticide remains in soils and waters in Morocco, [in:] Danh N.T. (ed.), Morocco. Environmental, social and economic issues of the 21st century, Nova Sci. Pulish., New York: 121-164.

Iken I., Hoummani H., Derkaoui A., Boukatta I., Oulfakir S., Bardai A., Harandou M., Khatouf M., Kanjaa N., Achour S., 2018, The poisoning by the chloralose: Experience of the university hospital Hassan II of Fez between 2011 and 2014, Toxicol. Anal. et Clin. 30(2): 114-119.

Jouzel J.-N., Prete G., 2014, Devenir victime des pesticides. Le recours au droit et ses effets sur la mobilisation des agriculteurs Phyto-victimes (Becoming a victim of pesticides. Legal action and its effects on the mobilisation of affected farmworkers), Sociol. Trav. 56: 435-453 (in French).

Kim S.-K., 2020, Trophic transfer of organochlorine pesticides through food-chain in coastal marine ecosystem, Environ. Eng. Res. 25(1): 43-51.

Koroša A., Auersperger P., Mali N., 2016, determination of micro-organic contaminants in groundwater (Maribor, Slovenia), Sci. Total Environ. 571: 1419-1431.

Kpan Kpan G.K., Yao L.B., Diemeleou C.A., N'guettia R.K., Traore S.K., Dembele A., 2019, Pratiques phytosanitaires en agriculture périurbaine et contamination des denrées par les pesticides: Cas des maraîchers de Port-Bouët, Abidjan (Phytosanitary practices in peri- urban agriculture and food contamination by pesticides: The case of market gardeners in Port-Bouët, Abidjan), J. Anim. Plant Sci. 41(1): 6847-6863 (in French).

Krakowiak A., Zajdel R., Kobza-Sindlewska K., Krakowiak M., Piekarska-Wijatkowska A., 2019, Pesticide poisonings in 2004-2014 in Łódź, Poland - an nalysis of selected clinical and sociodemographic parameters, Med. Pr. 70(6): 655-667.

Lee T.-G., Lee C.-G., Hong S.-G., Kim J.-H., Park S.-J., 2019, Water and soil properties in organic and conventional paddies throughout the rice cultivation cycle in South Korea, Environ. Eng. Res. 24(1): 45-53.

Velkoska-Markovska L., Petanovska-Ilievska B., Markovski A., 2019, determination of some pesticide residues in apple juice by high-performance liquid chromatography, J. Agric. Food Environ. Sci. (JAFES) 73(3): 30-37.

Liu Y., Fan X., Zhang T., He W., Song F., 2020, Effects of the long-term application of atrazine on soil enzyme activity and bacterial community structure in farmlands in China, Environ. Pollut. 262: \#114264.

Maatala N., Fadloui A., Lebailly P., 2019, Evaluation of the impact of partnership program on the technical and economic efficiency of irrigation water use for Moroccan citrus farms, Int. J. Agric. Econ. 4(2): 7079.

Maftouh I., Moussaif A., Elmzibri M., Elabbadi N., Mesfioui A., 2017, Assessment of the Main Active Molecules among the most used pesticides in the Gharb Region in Morocco, Int. J. Agric. Innov. Res. (IJAIR) 6(2): 359-362.

Marutescu L., Chifiriuc M.C., 2017, Molecular mechanisms of pesticides toxicity, [in:] Grumezescu A.M. (ed), New pesticides and soil sensors, Academic Press, San Diego: 393-435.

Mehmeti A., Musa F., Demaj J., Kamberi M., Rusinovci I., Kastrati R., 2016, The effect of herbicides on the chemical content of wheat grain, Agric. For. (Podgorica) 62(3): 117-123.

Ngakiama G.N., Mbela G.K., Pole C.S., Kyela C.M., Komanda J.A., 2019, Analyse des connaissances, attitudes et pratiques des maraîchers de la Ville de Kinshasa en rapport avec l'utilisation des pesticides et l'impact sur la santé humaine et sur l'environnement (Analysis of the knowledge, attitudes and practices of market gardeners in the City of Kinshasa in relation to the use of pesticides and the impact on human health and the environment), Int. J. Innovat. Appl. Stud. (IJIAS) 26(2): 345-356 (in French).

Oumenskou H., El Baghdadi M., Barakat A., Aquit M., Ennaji W., Karroum L.A., Aadraoui M., 2018, Assessment of the heavy metal contamination using GIS-based approach and pollution indices in agricultural soils from Beni Amir irrigated perimeter, Tadla plain, Morocco, Arab. J. Geosci. 11(22): \#692.

Rahhal B.M., Abu Rmileh J., Kalouti N., Murrar S., 2017, 
Assessment of respiratory health indicators among agricultural workers exposed to pesticides: A cross sectional study from Palestine, Mor. J. Chem. 5(2): 266-271.

Randhavane S.B., 2019, Comparing geometric parameters of a hydrodynamic cavitation process treating pesticide effluent, Environ. Eng. Res. 24(2): 318-323.

Rastija V., Agić D., Brlas K., Masand V., 2017, Application a new PyMOL plugin in quantitative structure-toxicity relationship study of pesticides, WSEAS Trans. Biol. Biomed. 14: 105-111.

Reiler E., Jřrs E., Bćlum J., Huici O., Alvarez Caero M.M., Cedergreen N., 2015, The influence of tomato processing on residues of organochlorine and organophosphate insecticides and their associated dietary risk, Sci. Total Environ. 527-528: 262-269.

Rhalem N., Khattabi A., Achour S., Soulaymani A., Bencheikh R.S., 2009, Facteurs prédictifs de gravité de l'intoxication aux pesticides. Expérience du Centre Antipoison Du Maroc (Risk factors for acute pesticide poisoning. Poison Control Centre of Morocco experience), Ann. Toxicol. Anal. 21: 79-84 (in French, English summary).

Rojano-Delgado A.M., Cruz-Hipolito H., De Prado R., Luque de Castro M.D., Rodríguez Franco A., 2012, Limited uptake, translocation and enhanced metabolic degradation contribute to glyphosate tolerance in
Mucuna pruriens var. utilis plants, Phytochemistry 73 : 34-41.

Samadi-Maybodi A., Rahmati A., 2019, Dual metal zeolitic imidazolate frameworks as an organometallic polymer for effective adsorption of chlorpyrifos in aqueous solution, Environ. Eng. Res. 25(6): 847-853.

Singare P.U., 2016, distribution and risk assessment of suspected endocrine-disrupting pesticides in creek water of Mumbai, India, Mar. Pollut. Bull. 102(1): 72-83.

Srad'ri M.T., 2017, New challenges for the Moroccan agricultural sector to cope with local and global changes, [in:] Danh N.T. (ed.), Morocco. Environmental, social and economic issues of the 21st century, Nova Sci. Pulish., New York: 165-188.

Tadeo J.L, Sanchez-Brunete C., González L.,2008, Pesticides: Classification and properties, [in:] Tadeo J.L. (ed.), Analysis of pesticides in food and environmental samples, CRC Press, Boca Raton: 1-34.

Walton E.L., 2016, Pralidoxime and pesticide poisoning: A question of severity? Biomed. J. 39 (6): 373-75.

[WHO] World Health Organization, 2020, International Program on Chemical Safety. Poisoning Prevention and Management. Harmonized data collection (Accessed 16 February 2020). Retrieved from http:// www.who.int/ipcs/poisons/en/ 